\title{
Blurring the Lines \\ Ritual and Relationships between Babongo Pygmies and their Neighbours (Gabon)
}

Julien Bonhomme, Magali De Ruyter, Guy-Max Moussavou ${ }^{1}$

"We take our revenge on our masters using fetishes, by making them drink our saliva in herbal infusions and other potions."

A Congolese Babongo Pygmy

On the $30^{\text {th }}$ of June 1865 , whilst exploring the mountain range in Gabon that now bears his name, Paul Du Chaillu visited an encampment of "Obongos", or "dwarfed wild negroes" (1867: 315). He was the first European to come into contact with Pygmies and to give a precise description of their way of life $^{3}$. Although they were the first to have contact with Europeans, Gabonese Pygmies are the least well known of the Central African Pygmy groups, doubtless because they fail to conform to the stereotype of forest-dwelling huntergatherers. The scanty literature devoted to them includes a few linguistic texts (RapondaWalker 1996 [1937], Mayer 1987), some rather unreliable work by ethnologically-minded

${ }^{1}$ The article was written by J. Bonhomme and M. De Ruyter. The ethnography on which it is based is derived from fieldwork conducted by J. Bonhomme, M. De Ruyter and G.M. Moussavou. The article has been translated from French by Matthew Carey.

${ }^{2}$ Cited in Gambeg, Gami \& Bigombe Logo 2006: 137.

${ }^{3} \mathrm{Du}$ Chaillu does not use the term "Pygmy" in his travel writings, published in 1867. It is only in his 1872 opus, The Country of the Dwarfs, a prettified version for children, that he uses it, following the example of Georg Schweinfurth, who had encountered an Akka "Pygmy" at the court of the Mangbetu king in 1870 . There, he also makes the connection to Graeco-Roman legends about Pygmies. 
missionaries (Le Roy 1928, Trilles 1932 - for a critique, see Mary 2010) and a few short introductory articles written by specialists on other Pygmy groups (Joiris 1997, Bahuchet 2007). The first work that stands out is by Efraim Andersson (1983), a Swedish missionary and anthropologist who spent time with Congolese and Gabonese Pygmies in the 1930s and 1940s. Only recently has more dedicated work on Gabonese Pygmies begun to appear (Knight 2003, Matsuura passim, Soengas 2009).

As Du Chaillu remarked, relations with neighbouring populations are an essential aspect of Pygmies' social life. In this article, we focus on relations between Babongo Pygmies (Du Chaillu's “Obongos") and their neighbours, highlighting the ambivalence of such ties. This ambivalence, we argue, is a question of differing perspectives in that it results from the two parties' asymmetric points of view regarding the relationship. The article then examines the ways in which interethnic relations are performed in initiation rites. Relations between the Babongo and their neighbours emerge in ritual contexts as singularly complex phenomena. This is, in part, because mythical representations of Pygmies play an important role in the neighbours' rituals and, in part, because the Babongo also participate in them. The clearest example of this imbrication is an initiation rite known as Bwiti, whose origins are sometimes attributed to the Babongo and sometimes to their neighbours.

This ethnographic puzzle in turn allows us to address three questions of wider anthropological import: the relationship between ritual and social organisation; that between myth and ritual or, to be precise, between representations and action in ritual contexts; and the dynamics of change in the sphere of initiation. If, as we claim, the relationship between ritual and social organisation can be construed neither as matter of simple reflection, nor as one of radical disconnection, then how does ritual re-enact relations formed outside its domain? This question is made more complex still by the Pygmies' dual presence within these initiation rituals, where they are present both as mythical representations and as practical participants. 
Far from overlapping, these two forms of presence produce a tension between the respect accorded to the Pygmies in local myths and their practical ritual subordination. Dynamics of change in the sphere of initiation reconfigure this tension, as the Babongo enact their neighbours' myth via their active participation in a new branch of the initiation rite. This transformation in the Babongo's ritual status occurs thanks to an alteration in the balance of power between the political, religious and therapeutical dimensions of the sphere of initiation. In order to situate the Babongo case within wider patterns of ritual logic and dynamics of ritual change within the region, our analysis extensively draws on comparative materials from other Pygmy groups. This article not only constitutes a significant contribution to the ethnography of Central African Pygmies (Bahuchet 1991), but also engages with anthropological approaches to the complex relational dynamics of ritual action (Kapferer 1979, Handelman 1990, Houseman \& Severi 1998, Gell 1998, Houseman 2006, Bonhomme 2006).

\section{A QUESTION OF PERSPECTIVE: RELATIONS BETWEEN BABONGO PYGMIES AND THEIR NEIGHBOURS}

Numbering several thousand people in total, Gabon's Pygmy population is broken up into various small groups scattered throughout the country (Knight 2003). The Baka Pygmies from the Minvoul region (in the north-east of the country) recently arrived from Cameroon and are distinguished by their more mobile lifestyle, their yodelled and contrapuntal polyphonies and by their use of an Oubangian language in an exclusively Bantu environment. The other Pygmy groups have longer-standing relationships with their neighbours and live in nearby villages or in mixed communities. In the early twentieth century, the now all but vanished Akoa lived among the Myene in the coastal regions, from the Gabon Estuary to the Fernan-Vaz lagoon. The Bakoya, who are also to be found in the Congo, live in the Mekambo 
region in the east of the country. The Babongo are distributed between the Chaillu mountains, where they live alongside the Mitsogo, in the intermediary zone between Ikobey and Eteke, and alongside the Masango between Mimongo and Koulamoutou (see Map) ${ }^{4}$. In the same region, they also have contacts with the Bavove, Simba and Apindji, who belong to the same ethnolinguistic cluster as the Mitsogo. Further south, they can be found towards Mbigou and Pana, among the Banzebi, and even on the other side of the Congolese border. They are present in smaller numbers as far east as Latoursville and Franceville. In the very south of the country, the Barimba of the Tchibanga region (who live alongside the Bapunu and the Bavungu) and the Bagama of the Mayumba region (who live with the Balumbu and the Bavili) should perhaps be considered part of the wider Babongo population (Andersson 1983: 2). Indeed, as Pygmy groups live in close association with their neighbours, it is not always clear whether their different names are autonyms or heteronyms.

As well as these various ethnonyms, the term "Pygmée" has been reappropriated by those it describes and is widely employed in the local Gabonese dialect of French ${ }^{5}$. Though the term is laden with negative stereotypes and has been accordingly criticised in the literature, we have chosen to keep it as a local category as a means of emphasising the Babongo's singular position in the local ethnic mosaic. The ties that bind Pygmies and their neighbours are seen by the latter not as something contingent, but as a form of relationality that is both generalised and systemic: as we were repeatedly informed, "Every race has its Pygmies". Even "Whites" are seen as having Pygmies of their own, which two of our

${ }^{4}$ GPS coordinates of settlements based on personal research, cross-checked with datas by Knight (2003) and Matsuura (2006).

${ }^{5}$ For a discussion of the Western invention of Pygmies, see Bahuchet $1993 \mathrm{~b}$.

${ }^{6}$ In local French, the word "race" signifies ethnic group. 


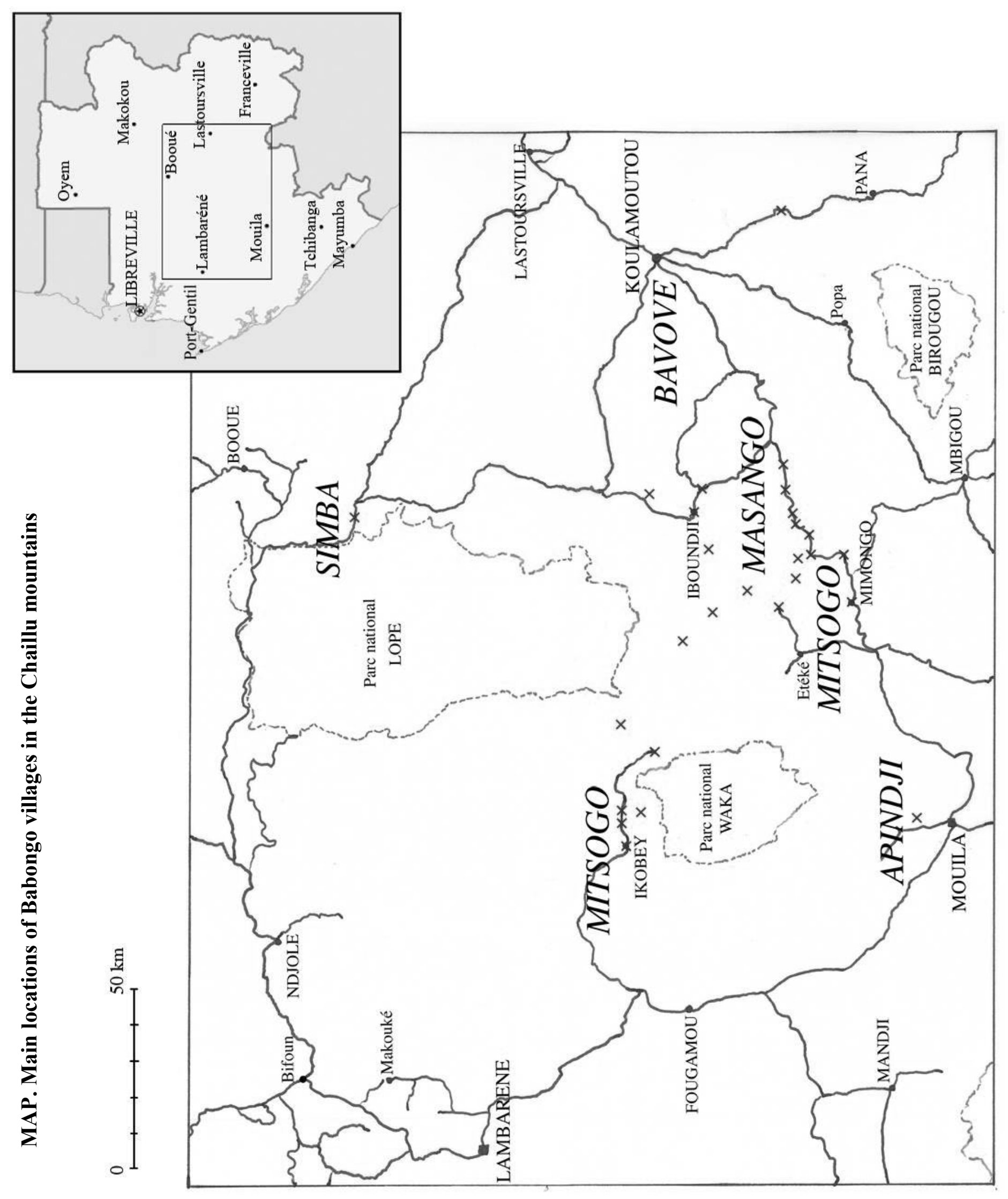


interlocutors glossed as Jews and Eskimos. From the point of view of the people themselves, the distinction between the Babongo and their neighbours is of a different order to the distinction between other ethnic groups. This is why we cannot limit ourselves to ethnonyms, which might reinforce the idea of identity as something both self-sufficient and substantive (Bazin 1985). The term "Pygmy" has the signal advantage of emphasising the perspectivist logic at the heart of relations between the Babongo and their neighbours. Indeed, these interethnic relations cannot be considered in isolation from the two parties' representations of their respective identities and of the fundamental nature of their relations (Bahuchet \& Guillaume 1979: 111). Thus, the term "Pygmies" denotes the Babongo as they are perceived by their neighbours, just as the French word "Noirs" (Blacks) symmetrically denotes neighbouring populations as they are perceived by the Babongo.

Local perceptions of "Pygmies" are structured by both physical and sociocultural stereotypes: they are short and light-skinned and they live from hunting in the forest. This distinction between Pygmies and their neighbours has its roots far back in history. Recent studies in population genetics situate the point of separation between Pygmies' ancestors and their neighbours' at least 60,000 years ago (Quintana-Murci 2008, Verdu 2009, Patin 2009)7. Which is not to suggest that Pygmies constitute a homogeneous population: Central and West African Pygmies separated off more than 20,000 years ago. And a second separation occurred roughly 3,000 years ago, probably sparked off by the neolithic revolution and Bantu expansion into Central Africa. This led to the emergence of contemporary Pygmy groups, as a wave of migration by agricultural populations pushed hunter-gatherers into the forests. The

\footnotetext{
${ }^{7}$ Though social anthropologists must of course be prudent in their use of such data (as culture cannot be mapped onto genes), this work nonethless opens up a window on Africa's distant past.
} 
introduction of metallurgy (ca. $500 \mathrm{BCE}$ in Gabon) and bananas enshrined the economic and demographic superiority of agriculturalists (Klieman 2003). Pygmy hunter-gatherer communities became isolated from one another, but at the same time began to maintain steady relations with their agricultural neighbours, as attested to by gene flow indicating intermarriage. Thus, Western Pygmies are today genetically closer to their agricultural neighbours than to Eastern Pygmies. Among Western Pygmies, the Babongo stand out as the group most genetically proximate to its neighbours (Verdu 2009). Though such long-term historical reconstructions are problematic, they have the signal virtue of situating Pygmies firmly within history, rather than assigning them the role of ahistorical hunter-gatherers somehow emerging straight out of the Paleolithic era (Headland \& Reid 1989, Blench 1999). They allow us to stress the importance and historical depth of relations between Pygmies and their neighbours, who are better thought of as "two ethnic groups forming one society, than as two separate societies" (Grinker 1990: 112). The ethnic boundary that separates them does not exist in spite of their social interactions, but by virtue of them ${ }^{8}$. The two groups' interactions are based on a form complementary specialisation that directs their lifestyles: Pygmies' specialisation in forest products finds its counterpart in the increasing agricultural specialisation of their neighbours. This interdependence relies on a system of exchanges: agricultural and craft products are traded for the produce of hunting and gathering. The most prestigious form of exchange sees iron traded for game.

It is impossible to say for sure whether the agriculturalists' economic and demographic superiority was always accompanied by political ascendency, or whether relations between Pygmies and their neighbours remained relatively egalitarian. What is clear is that contact with Europeans shifted things in favour of the agriculturalists, as Pygmies are now also

\footnotetext{
${ }^{8}$ For a discussion of the notion of ethnic boundary, see Barth 1969.
} 
dependent on their neighbours' control of the long-distance trade networks that bring them European consumer items. Pygmies also provide cheap ivory that their neighbours sell on to Europeans at a profit ${ }^{9}$. The villagers' economic domination leads to the social marginalisation of the Pygmies, who are relegated to an inferior and dependent class. The villagers' perspective is then legitimised by ideological representations wherein they portray themselves as the Pygmies" "masters" or "patrons", describing them as "slaves" and thus reproducing relational schemas born out of colonialism and the slave trade. The Mitsogo even claim that until recently the Babongo were used as a back-up source of sacrificial victims for certain rituals. These are not, however, precise representations of the reality of their relations. Pygmies have never been the agriculturalists' slaves strictu sensu, and in any case, the status of dependents in the region is of a far more varied and porous nature than the Western notion of slavery would lead us to expect (Rey 1971). Moreover, Gabonese Pygmies' position in the interethnic system at the heart of the slave trade remains unclear. For instance, many Mitsogo were enslaved and sold from group to group until they reached the coast. The same is perhaps true of the Babongo (Raponda-Walker 2002 [1960], Knight 2003), and it likely the case that so called "Akoa" Pygmies are in fact descendants of Pygmy populations from the interior who arrived on the coast by way of slavery. That said, the Babongo's limited numbers, relative isolation in the forest and more nomadic lifestyle make it unlikely that they were significantly involved in the slave trade.

This representation of the Pygmy as slave coexists alongside an equally derogatory representation of them as animals: relegated to the margins of humanity, they are depicted as closer to monkeys than men. One Fang syncretic myth attributes their origins to Cain's

\footnotetext{
${ }^{9}$ As early as 1686 , Olfert Dapper remarked that the kingdom of Loango procured ivory from “dwarves” called "Backébackés".
} 
miscegenation with a chimpanzee (Swiderski 1979: 194). This idea of Pygmies as somehow bestial is remarkably close to the Western myth of the missing link, which played an important part in racial and evolutionist visions of Pygmies within anthropology, although it is unclear whether or not there is a direct link between the two ${ }^{10}$. This stigmatisation is aided by the attribution of a distinctive ethos to Pygmies - one which underlines their proximity to the animal kingdom. According to one Bapunu woman from Libreville, "Pygmies go around naked. They smell bad. And they speak poorly". This derogatory representation is also used to justify more brutal behaviour: as one man from Ikobey put it, "Pygmies are almost human. You have to be brutal with them or they'll mess you around. If you don't scare them, they won't tell you anything”. The real state of relations between Gabonese Pygmies and their neighbours varies, however, from group to group: the Babongo are, for instance, treated less badly than the Baka, who are violently stigmatised by their Fang neighbours (Cheyssial 2000).

Asymmetrical relations between Pygmies and their neighbours are reflected in group names. Most of the time, the Babongo are called (and call themselves) "the Mitsogo's Babongo" (Abongo a Mitsogo) or "the Masango's Babongo" (Babongu ba Masangu), which is much as it was when Du Chaillu remarked that "the Obongos [Babongo] who live within the Ashango [Masango] territory do not go out of that territory - they are called the Obongos of the Ashangos - those who live among the Njavi [Banzebi] are called Obongo-Njavi - and the same with other tribes" (1867: 323). This appellation differentiates between sub-groups by residence, but the particle "a" or "ba" is also a possessive. Indeed, some Mitsogo and Masango consider themselves to be the "owners" of the Babongo families that their ancestors "brought out of the forest" and sedentarised at their sides in roadside villages. Such families

\footnotetext{
${ }^{10}$ See Bahuchet 1993 b for a discussion of this trend.
} 
must perform certain chores (hunting, agricultural labour) for their owners, who offer, in return, a more or less unspecified form of protection and who take responsibility for lifecycle rituals (marriage, initiation, funerals). Owners may even act as administrative guardians for "their" Babongo. As one Mitsogo man from Mimongo said to us, "When there are elections, I draw up the list of my people".

This asymmetry results in a culture of dependency: the Babongo's is a culture based on borrowings. "Bringing the Babongo out of the forest" was a "civilizing act". Villagers claim that they introduced the Babongo to clan exogamy: "The Babongo adopted the clan affiliation of the Mitsogo who brought them out of the forest. Before, the Babongo just got married to whomever, fathers with daughters". The Babongo have the same social organisation as their neighbours and belong to the same clans. Many Mitsogo even claim that the Babongo have no culture of their own and that they learnt everything from their neighbours. Language is a good indicator of this tenuous cultural demarcation, especially as the vernacular terms usually translated as "ethnic group" actually designate the spoken idiom first and foremost (such as "eongo", in Getsogo, the language of the Mitsogo). All Central African Pygmy languages are related to the languages spoken by their neighbours, past or present, and the lingua franca is always the neighbours'. In the Chaillu mountains, the Babongo speak Getsogo or Yisangu (the Masango language), but among themselves they also speak Ebongwe, which the Mitsogo claim they do not really understand. It is, however, linguistically very close to Getsogo, Gevove (the Bavove language) and Gehimbaka (the Simba language), although it differs in its system of classes, in terms of intonation and also by virtue of a number of unique expressions. Du Chaillu remarked that the Babongo language was "a mixture of what was their own original language and the languages of the various tribes among whom they have resided for many years past" (1867: 323). Although the existence of a Pygmy protolanguage has never been verified, the idea that Babongo is a 
linguistic hybrid is supported by André Raponda-Walker (1996 [1937]: 7), who wrote the only Ebongwe grammar to appear to date.

It thus appears that the opposition between Bantu and Pygmies defended by numerous authors falls down in the Babongo case, as they speak a Bantu language. Nor is the classical distinction between nomadic hunter-gatherers and sedentary agriculturalists of much relevance to the present-day situation. The policy of resettlement in roadside villages carried out in Gabon since the 1940s has brought the Babongo out of their forests and sedentarised them (Knight 2003). The most we can say is that they maintain a more mobile way of life than their neighbours and spend more time in the forest encampments, where they sometimes preserve their traditional huts. Their sedentarisation has been accompanied by a shift towards agriculture. Du Chaillu commented on the absence of Babongo plantations in the midnineteenth century, but slash-and-burn agriculture emerged by the 1940s (which is to say, quite early in comparison to other Pygmy groups), as attested to by Andersson (1983: 22-24). The production of basic foodstuffs for which they had previously been dependent on their neighbours afforded the Pygmies a greater degree of autonomy vis-a-vis these latter (Althabe 1965, Guille-Escuret 1998). They are, however, rarely self-sufficient in food-crops. As one Masango from Mukandi complained to us, “The Babongo's plantations are too small. When they've eaten everything, they come and steal from ours. We make them clear our new plantations as punishment, but it never stops them". This accusation of theft from plantations constantly recurs in neighbours' discourses on Pygmies and implicitly reveals the Babongo's decision not to give themselves over entirely to agriculture, but to cling on to a forest way of life - in short "to remain specialised hunter-gatherers in the world of agriculturalists to which they now belong" (Bahuchet 1993a: 153).

Depending on one's point of view, the Babongo's shift towards sedentary agriculture can be construed as a form of cultural alienation signalling increased dependence upon their 
neighbours or, on the contrary, as a step towards equality with them. This uncertainty speaks to the ambivalence of relations between Pygmies and their neighbours, which encompass “interdependence, latent hostility and mutual attraction” (Arom \& Thomas 1974: 90). This ambivalent is evident in intermarriages, which invariably see Black men marrying Pygmy women. This hypergamy reproduces ethnic subordination - as one Bakoya from OgoouéIvindo man put it, "You will never see Pygmy [men] marrying [women from] other races, because they don't like us. They just want to make children in Pygmy [women's] bellies. They say we have tails [like monkeys], but they marry our women. Have you ever seen a man marry a monkey?" In such intermarriages, the wife's family is habitually cut off in favour of her husband. The Babongo are notable among Pygmy groups for the number and probably the historical depth of intermarriages with their neighbours, and sometimes Pygmy men even marry Mitsogo or Masango women, which would be unthinkable for Baka Pygmies living alongside the Fang and most other Pygmy groups. Although the Babongo's neighbours tend to hush up such unions, the fact remains that mixed marriages do create a sort of interethnic solidarity.

The existence of such forms of solidarity between Pygmies and their neigbours has led some authors to challenge the prevailing paradigm of interethnic domination. So Jean-Michel Delobeau (1989) speaks of an "association" between Aka Pygmies and the Monzombo in the Central African Republic, whilst Hideaki Terashima (1998) goes so far as to describe relations between Efe Pygmies and the Lese (DR Congo) as "symbiotic". Pygmies and their neighbours often formalise their relations in symmetrical partnerships that go far beyond mere economic exchanges: ritual friendship, blood pact, fictive kinship and participation in initiation rites (Rupp 2003). The first three forms of partnership do not really exist among the Babongo, but participation in initiation rites plays, as we shall see, a key role in interethnic relations. Naoki Matsuura (2006) suggests that relations between the Babongo and their 
neighbours better fits a solidarity model than a domination one and might even be conceptualised as assimilation. He further claims that the Babongo and the Masango have developed more or less equal relations which tend to erase their differences. They live together in villages, cooperate in agricultural tasks, marry one another and participate in the same rituals. And yet, despite all this, the Babongo and the Masango maintain the ethnic boundary that divides them.

Pygmy ethnography thus oscillates both between an "ideology of domination" and an "ideology of solidarity" (Joiris 2003), and between an ideology of dependence and an ideology of autonomy. The differing perspectives of various anthropologists play, of course, their part in this, but such ambivalence is also part and parcel of the local context, as Colin Turnbull and Paul Schebesta's seminal debate about the Mbuti makes clear. Schebesta described the Efe-Mbuti as "vassals" tied into "a more or less tyrannical relation of submission" to their village "patrons" (1940: 59-60). Turnbull (1965), on the other hand, insisted on the Mbuti's autonomy. These latter switch back and forth between two opposing worlds, the "village world" and the "forest world". Though villagers may try to control the Mbuti when they are present in the village, this control is always contingent; the Mbuti retain the initiative and can always go back to the forest if they are unhappy with the situation. Once away from the "noise" of the village, the Mbuti regain their autonomy. In truth, the controversy between Turnbull and Schebesta is a matter of perspective. The former came into contact with the Pygmies via the villagers and so "saw Pygmy society from the point of view of village society" (Museur 1969: 157). Turnbull's perspective, on the other hand, is conditioned by having lived in the forest with the Mbuti and "reflects the Pygmies' view of themselves" (ibid.). Schebesta describes Pygmy-villager relations from the latter's point of view, whereas Turnbull approaches them from the former's. This is not to suggest that Schebesta was wrong and that Turnbull described the Mbuti "as they really are". Turnbull's 
vision of the Pygmies' harmonious life in the forest is the product of a romantic fascination that has marked the literature to a considerable extent (Frankland 1999). What is more, one cannot argue that only the Pygmies' point of view is acceptable as their relations with their neighbours is part and parcel of their identity. Pygmy ethnography has to take into account not only Pygmy-villager relations but also their different perspectives on these relations.

As the Babongo case clearly shows, this perspectivist logic is not symmetrical. The Babongo's point of view introduces a further layer of complexity that their neighbours' lack. The Babongo are past masters in the art of seeing themselves as others see them and playing on this. This reflexive capacity to adopt the other's perspective is particular to them (the Mitsogo would never try to see themselves from the Pygmies' point of view) and it is a product of the asymmetry of their relations: Pygmies perceive themselves in terms of the dominant group's categories. One often hears the Babongo mockingly refer to one another as "Pygmies". This propensity to see themselves as "Pygmies" is less a symptom of their alienation than an ironic subversion of existing stereotypes that affords them a degree of liberty $^{11}$. In front of their neighbours, the Babongo frequently adopt the latter's point of view, living up as much as possible to the stereotype of "the Pygmy". This strategy of dissimulation is a true weapon of the weak and makes the ethnographer's work significantly more complicated. Everything becomes a question of interlocutory situations: Who is speaking? In what context? In front of whom? This subversive play with others' perspectives means that one can never tell where the Babongo "really" stand, if indeed one can assign them a fixed place at all. The Pygmies' reputation as slippery customers is exactly parallelled by their

\footnotetext{
${ }^{11}$ Much as with the use of the word "nigger" in North America, the term "Pygmy" has been reapproriated by the stigmatised group. It is often used in an ironic fashion, but is sometimes invoked as part of an assertion of ethnic identity which sees its derogatory qualities inverted.
} 
performance of evasion. As one Mitsogo man from Mimongo said to us, "the Pygmies are very cunning, they love to blur the lines" $" 12$.

\section{THE MYTHICAL FIGURE OF THE PYGMY IN THEIR NEIGHBOURS' RITES}

Relations between Pygmies and their neighbours become more complicated still in the ritual sphere. The foremost reason for this is the important role that Pygmies play in their neighbours' rituals. Among the Ngbaka of the Central African Republic, hunters use songs to propitiate trapper spirits known as mimbó. These spirits, who are meant to guide game towards the traps, are in fact representations of neighbouring Aka Pygmy spirits (Arom \& Thomas 1974). The Bahemba of Lake Tanganyika also have a cynegetic rite called Múhùngú, where they employ small sculptures representing the spirits of Batswa Pygmy hunters (Kazadi 1981). The Bahemba are also susceptible to possession by the spirits of dead Pygmies who return to take revenge on the descendants of their former masters. Initiation into the Bútèmbó possession cult allows them to stabilise their relationship to these spirits whilst putting them to work for the benefit of the community. As the discrepancy between actual Pygmies and ritual representations of them makes clear, rites are a means of playing out interethnic relations on another level.

Ritual relations between Pygmies and their neighbours are further complicated by their shared participation in numerous rituals. This mutual participation in the other group's rituals sometimes leads to such overlap that it is no longer clear whose they originally were. So Schebesta aptly remarks that it is "difficult to distinguish between the Bambuti and Blacks in

\footnotetext{
12 The French expression used by our informant was "brouiller les pistes". It could be translated as "blurring the lines" or "covering one's tracks". The word "piste" also alludes to the footpaths used by Pygmies in the forest.
} 
the religious and spiritual spheres" (1940: 89). Turnbull, on the other hand, tries to demonstrate that the Mbuti have their own rituals quite distinct from those of their neighbours, although some of his own observations appear to undermine this claim. In an article published in 1957, he looks at male initiation among the Mbuti. This initiation rite, which he calls Lusumba and which is carried out when a young man makes his first big kill, signals the culmination of his integration into the community of hunters. Ceremonies are also organised in situations of famine, illness or death in order to "awaken" the forest spirit and bring down his benevolence. In Wayward Servants (1965), however, Turnbull disavows his use of the term "Lusumba", stating that this is the villagers' word for one of their own rituals and that the true Mbuti name is "Molimo" (1965: 25). He also suggests that some Molimo ritual chants are in fact derived from the neighbours' Nkumbi male initiation rites, in which the Mbuti also take part (ibid.: 77-80). From the villagers' point of view, the Molimo is nothing more than a clumsy imitation of their own songs. Although, that said, in the presence of outsiders, the Mbuti will only perform a fake Molimo in which they parody the villagers' Lusumba rite by imitating their inelegant and elephantine demeanour (Turnbull 1960: 39). The situation is further confused by the fact that villagers have their own funerary rite called Molimo $^{13}$.

This complex tangle of different rituals is equally present in the Chaillu mountains, which boast a dozen distinct initiation societies (see Table). These initiations encompass both coming-of-age rites (which are obligatory, collective and sexually segregated) and rites of affliction (which are contextually dependent, individual and sometimes mixed). Some rituals (Bwiti, Mwiri, Nyembe) are widespread throughout the region, whilst others are restricted to

\footnotetext{
${ }^{13}$ The situation is no less complicated when it comes to the Elima, a female Mbuti initiation rite that bears the same name as that of neighbouring villagers.
} 


\begin{tabular}{|c|c|c|c|c|c|c|c|}
\hline RITUALS & TYPE OF RITUAL & SEX & $\begin{array}{c}\text { SOURCE } \\
\text { POPULATION }\end{array}$ & $\begin{array}{c}\text { ORIGIN } \\
\text { MYTH }\end{array}$ & MEMBERSHIP & $\begin{array}{l}\text { PYGMIES' } \\
\text { STATUS }\end{array}$ & COMMENTS \\
\hline Mudimu & Rite of passage linked to first big game kill & \multirow[t]{2}{*}{$\hat{0}$} & \multirow[t]{2}{*}{ Babongo Pygmies } & \multirow[t]{2}{*}{$\varnothing$} & \multirow[t]{2}{*}{ Babongo Pygmies } & \multirow[t]{2}{*}{ Sole actors } & Principally, but not exclusively male (rare cases of female initiates) \\
\hline$\hookrightarrow$ Buluma & Propitiatory hunting prayer & & & & & & Linked to Mudimu. Incorporated into Bwiti Misoko as a ritual sequence \\
\hline Mwiri & Initiatory rite of passage to adulthood & $\hat{o}$ & non-Pygmy & 우 & Anybody & Initiates & \\
\hline Nyembe & Initiatory rite of passage to adulthood & 우 & non-Pygmy & $\hat{0}$ & Anybody & Initiates & \\
\hline Bwiti & Vision-centred initiation & & non-Pygmy & \multirow[t]{6}{*}{ o, Pygmies } & \multirow[t]{6}{*}{ Anybody } & Initiates & Ritual overlap of mythical representations of Pygmies and their actual participation \\
\hline$\hookrightarrow$ Disumba & $\hookrightarrow$ Religious initiation (ancestor cult) & $\hat{0}$ & $\hookrightarrow$ Mitsogo, Apindji & & & $\hookrightarrow$ subordinate actors & \\
\hline$\hookrightarrow$ Misoko & $\hookrightarrow$ Therapeutic initiation (healing cult) & & & & & \multirow[t]{4}{*}{$\hookrightarrow$ also initiators } & Emerged out of a process of regional ritual synthesis incorporating Pygmy elements \\
\hline$\hookrightarrow$ Myobe & $\iota_{\text {healing-centred }}$ & $\hat{0}$ & $\hookrightarrow$ Mitsogo & & & & Losing ground to Ngonde \\
\hline$\hookrightarrow$ Ngonde & \multirow[t]{2}{*}{$\hookrightarrow$ divination-centred } & $\hat{o}$ & \multirow[t]{2}{*}{$\hookrightarrow$ Bavove, Masango } & & & & Has experienced nationwide growth since the 1980s. Strong Babongo Pygmy involvement \\
\hline$\hookrightarrow$ Mabundi & & 운 & & & & & Initiates subordinate to Ngonde or independent branch of Misoko? Closely linked to Nyembe \\
\hline Bwiti Akoa & Dance of rejoicing & $\sigma^{\lambda}$ & Akoa Pygmies & Pygmies & Akoa Pygmies & Sole actors & Non-sacred dance derived from Bwiti Disumba: no real initiation; no visions \\
\hline Ombudi & Possession-centred therapeutic initiation & $q$ & non-Pygmy & 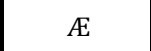 & Anybody & Initiates & Principally, but not exclusively, female. Many similar possession cults in the region \\
\hline
\end{tabular}

TABLE. Initiation rituals in the Chaillu mountains 
particular populations. Thus, the Babongo jealously guard their Mudimu, which they consider their principal ritual (even though it seems that some sub-groups don't perform it anymore). Although it has no particular distinguishing characteristics in terms of its musical structure, nobody contests the ritual's specifically Pygmy origin - which is somewhat reminiscent of the relationship between the Pygmy's Ebongwe language and the neighbouring Getsogo (De Ruyter 2003). The Babongo are quite open about participating in their neighbours' rites, but out of concern for their identity are notably more taciturn when it comes to the Mudimu: as one Babongo man from Mimongo put it, "We can't show everything. That's just not possible. We can give away the leaves, but the yam stays with us". When faced with outsiders (including anthropologists), they sometimes even try to pass off one of their neighbours' rituals as the Mudimu, thus screening their own ritual with another (just like the Mbuti do with the Molimo). This obfuscation is typical of the Babongo's tendency to blur the lines and cover their tracks. Mudimu initiation requires a wild yam, game and honey, all of which invoke the Babongo's distinctive activities: hunting and gathering. The ritual is a rite of passage organised when a young man kills his first bushpig with a spear. The animal's heart is then mixed with particular leaves and the young man has to eat it raw, with this "medicine" being presented to him on the tip of a spear by an initiated man. The ritual also sees the transmission of a symbolic knowledge linked to hunting and, more generally, to the Pygmies' origins. The initiation is normally described as "catching the Mudimu" or "catching the nyama [game]". The word Mudimu signifies the game's spirit master. Mudimu ceremonies may also be organised in the event of a bad hunt in order to propitiate the master of the game. The Babongo's Mudimu is a classic example of what we know of Pygmy rituals (Turnbull 1965, Bahuchet 1992, Joiris 1993, Tsuru 1998) ${ }^{14}$. These rituals are closely linked to hunting, and

\footnotetext{
${ }^{14}$ The similarities between Mudimu and the Mbuti's Molimo are striking. In both cases, it is
} 
most notably to hunting with spears - a specifically Pygmy activity. They are frequently concerned with propitiating masters of game. Most of them can also be held in the event of crisis, illness or death and are often combined with rites of passage connected with a hunter's first big game kill. These are closer to being simple rites of passage (which consecrate an event external to the ritual) than full-blown initiations (which create a new identity sui generis). This marks Pygmy rituals out from those of their neighbours (Boyer 1989).

Rituals are not symmetrically shared by the Babongo and their neighbours. Though the Mudimu is normally restricted to the Babongo, these latter are initiated into most of their neighbours' rituals. The two groups often organise collective initiation rites (Mwiri for men and Nyembe for women) and these are obligatory for the Babongo, just as they are for their neighbours. Whichever ethnic group they belong to, all young men are equally subject to initiatory hazing during the Mwiri. These shared rituals, according to Matsuura (2007), are proof of the equality of relations between the Babongo and their neighbours. However, such equality as there may be does not run very deep. It is mainly the Mitsogo and the Masango who control the initiation societies and act as cult leaders. For their neighbours, the Babongo's participation in initiation ceremonies is a sign of their dependence. Whereas for the Babongo, it is a means of attaining initiated adult status in the eyes of their neighbours ${ }^{15}$.

both a rite of passage and a rite of propitiation. What is more, the two words are cognate, which is even more remarkable when we consider that the term, which means "spirit" is absent from neighbouring Gabonese languages. That said, the two rituals are different in form.

${ }^{15}$ According to Turnbull (1957), the Mbuti's decision to be initiated into their neighbours' rite of passage is only indicative of a superficial adherence to the rite. For them, Nkumbi is apparently a rather grotesque theatre in which they participate without really believing in it. 
This ambivalence surrounding the Babongo's participation in their neighbours' rites is a question of perspective: what looks like equality from one point of view can look like domination from another. The diverging points of view between Matsuura and us regarding the Babongo's place in their neighbours' initiations partly derive from our respective field sites: the somewhat egalitarian relations between the Babongo and the Masango stand in contrast with the more unequal relations between the Babongo and the Mitsogo. Yet we argue that, behind the public façade, the ritual relations between the Babongo and the Masango are asymmetrical as well.

Among the rites shared by the Babongo and their neighbours, it is in Bwiti (or Bwete) that the relational situation is most entangled. Its principal branch, the Bwiti Disumba, is an obligatory male initiation ritual. It is less an initiatory rite of passage to adulthood (like the Mwiri) than a religious initiation that accords particular importance to visions and to the transmission of secret knowledge. The initiation centres around the ingestion of a plant-based hallucinogen called eboga (Tabernanthe iboga). The initiate's visionary journey takes him to the ancestors' mythical village. The Bwiti is based around an ancestor cult and the central cult objects, also called Bwiti, are reliquaries containing the skulls of the forefathers. Although the Babongo are normally initiated into the Bwiti Disumba in the same manner as their neighbours, the ritual's origins are a subject of controversy. In 1910, André Raponda-Walker remarked that "the Bouiti [sic] apparently comes from the Akoa, the Pygmies. It is also sometimes attributed to the Apindji and the Ashango" (1998 [1910]: 14). This question

And indeed, the initiation does not alter the social status of young Mbuti men back home. Whatever the case may be, this radical interpretation, which exalts the Pygmies' pragmatism whilst ridiculing their neighbours' credulity, does not apply to the Babongo's initiation into Mwiri. 
surrounding its origins is also of key importance to the initiates themselves, as the knowledge transmitted during the Bwiti is done so in genealogical terms: to know is to reach back to "the origin" (go ebando), all the way to the very first links in the initiatory chain of transmission (Bonhomme 2007). It is, however, difficult to distinguish between those parts that deal with Bwiti's actual transmission from one local population to another and those that concern its mythical origins. Both the Mitsogo and the Apindji (who are closely related) claim that they created the Bwiti and their neighbours often attribute it to them. This is also the most anthropologically convincing hypothesis. However, many initiates claim that the Bwiti's origins lie with the Pygmies. According to one Bapunu initiator from Libreville, "Bwiti is a religion created by our Pygmy ancestors in the virgin forest". And according to another Bapunu initiate, "it was the Pygmies who first practised the Bwiti. The Bwiti was performed in the bush, in the forest. Then the Mitsogo brought it back to the village". Yet another version attributes the Bwiti to Pygmy "half-bloods" or to those attached to their neighbours. As one Bavove initiator from Koulamoutou put it, "All the different branches of Bwiti come from the Pygmies. When people say it comes from the Mitsogo, that means it comes from the Mitsogo's Pygmies". Even those Mitsogo most hostile to the Babongo recognise that they played some part in its mythical creation: according to a Mitsogo initiate in Ikobey, Kombi, the Mitsogo man who created the Bwiti, supposedly had a Pygmy "brother", called Motsoyi, who created the "Pygmy version" of the ritual. Here again, the Bwiti's origins are all a matter of perspective. City-dwellers are more likely to attribute the Bwiti to the Babongo than are those who live alongside them, ${ }^{16}$ and the Mitsogo are less likely than others to do so. As for the Babongo themselves, their discourse varies. When asked, some claim that they created the

\footnotetext{
${ }^{16}$ For some city-dwellers, the term "Pygmy" indiscriminately describes all "bush people", encompassing Pygmies proper as well as their village neighbours.
} 
Bwiti, but others say they took it from their neighbours. This is a clear example of the Babongo's dual perspective, whereby they may represent themselves as either Pygmies or as Babongo. Their response depends on the context of utterance. Thus, during one interview with a Babongo man in Mukandi, a nearby Masango man commandeered the conversation and replied in the former's stead:

Guy-Max: Did the Babongo take the Nyembe (female initiation ritual) from the Masango? Babongo man: Our grandparents learned the Nyembe with the Masango.

Masango man (interrupting): All those sorts of things, the Ba-Misoko (a branch of the Bwiti), it's the Pygmies who are the autochthones there. Even with the Mwiri, the Nyembe, all of that, it's them the autochthones. They began it all. Us Masango, we developed it differently.

It is then the Masango man who attributes all the initiation rites to the Pygmies, and the Babongo man does not contradict him. The interview continues in the same vein and the Babongo man frequently models his response on his neighbour's point of view. The attribution of the Bwiti to the Pygmies is, then, more their neighbours' doing than their own. In any event, the idea that the Bwiti originates with the Pygmies sits unhappily with what we know of Pygmy societies - i.e. the absence of ancestor cults (with the dead becoming anonymous spirits roaming the forests) and a fortiori of cults based around relics (limited importance is given to the conservation and transmission of cult objects). The Bwiti's initiatory logic, just like its restriction to men, also fit poorly with what we know of Pygmy rituals, which are normally more flexible and characterised by less rigorous gender segregation.

The attribution of the Bwiti to Pygmies partakes then of the mythical order. The figure of "the Pygmy" features heavily in Bwiti myths. This is the case in the origin myth of the 
musical bow (mongongo), one of the two main instruments used during the Bwiti (the other being the Ngombi harp).

In the forest, a Pygmy falls from a tree and dies. His widow finds his body and informs the men back at the encampment. They use the dead man's innards to make the musical bow's vibrating string, his spine to form the body of the bow, and his tibia and radius to make sticks with which to strike the string and change the pitch.

The eboga's origin myth relies on a similar narrative schema:

In the forest, a Pygmy falls from a tree and dies. An eboga plant grows on the spot where he died. Later, the dead man appears to his widow in a dream and asks her to venture into the forest and eat the eboga's root. She does so and her husband appears before her. This is the origin of the Bwiti.

The initiates also say that their forefathers learnt about eboga from the Pygmies. They sometimes add that the Pygmies only used the eboga so as to be able to beat their drums without tiring. They made use of the plant's stimulating properties (when ingested in small doses), rather than its hallucinogenic properties (at higher dosages). The Pygmies' neighbours supposedly took the eboga and put its visionary properties to use in their own rituals. In the words of one Vili initiate in Mimongo, "The Bwiti comes from the Pygmies. Or rather, Pygmies discovered eboga by watching animals eat it. Then they gave it to the Mitsogo who built the Bwiti around it". This version situates the origins of Bwiti with the Pygmies, but stops short of giving them all the credit for it.

Pygmies as they appear in Bwiti myths have little in common with the actual Babongo as their neighbours know them. These mythical Pygmies correspond to an idealised figure who appears not just in Bwiti, but in the oral traditions of populations throughout Gabon as 
well as elsewhere in Central Africa ${ }^{17}$. This mythical figure takes shape about the image of the "primordial Pygmy" (Klieman 2003). The Pygmy is first and foremost seen as autochthonous and thus as the land's original owner (Vansina 1990: 56-57). Most migration narratives in Gabon describe meetings with Pygmies, the first inhabitants of the area, who guide the newcomers through the forest: they "were the compass", as one Bapunu man put it (Deschamps 1962: 25). Or in the words of a Mitsogo man, "We followed the Pygmies and they showed us the rivers, the peaks and the fruit trees. Back then, we were one family" (Sallée 1985: 236). Fang oral tradition tells that the Pygmies saved them by piercing a hole in a gigantic adzap tree (Mimusops djave) that blocked their path at the edge of the forest (Fernandez 1982: 57). The Pygmy qua forest-specialist acts as a necessary intermediary between the newcomers and this environment, which the villagers deem hostile and dangerous. He is seen as a mediator with the forest spirits, and sometimes even identified with them. The Pygmies' power is seen as proportional to how deep in the forest they live: the more invisible they are, the more powerful they are supposed to be. People also say that beyond the Babongo (now mainly sedentarised in roadside settlements), hidden in the forest, there are still "true" Pygmies to be found. This legend is based around the opposition between real Pygmies, visible to all, and the mythical Pygmy, who is by definition invisible. Indeed,

${ }^{17}$ Despite the current (and perhaps historical) absence of Pygmy groups in West Africa, similar representations are found throughout the region, mentioning small, pale-skinned men who specialise in hunting (Klaus Hamberger, personal communication). This contrast between Central Africa, where symbolic representations refer back to real populations, and West Africa, where these same representations exist in a referential vacuum, only serves to highlight the question of the true distance between the mythical Pygmy figure and actual Babongo. 
Pygmies have a reputation for being slippery or ungraspable. This is linked to several characteristic aspects of their behaviour as forest-dwellers: they live apart, move quickly and discretely, cover their tracks, and decamp when strangers arrive. But their neighbours also attribute to them magical powers of invisibility and even of animal metamorphosis.

The mythical Pygmy also represents the ancestor of humanity, a sort of Ur-ancestor who pre-exists lineage, clan and even ethnic notions of kinship. For one Bapunu woman, "Pygmies are the first men". Mitsogo oral tradition has it that the original ancestor, the "trailblazer" who came down from the village above to explore this world, was a Pygmy named Motsoyi (Gollnhofer \& Sillans 1997: 122). He brought with him the entirety of the human race or, in some versions, he engendered them with his wife Madombe, thus giving rise to all the different "races". This Pygmy ancestor is also the bringer of civilization. The Pygmies' neighbours often attribute to them the first use of fire and of cooked foods, of hunting dogs and trapping techniques, of weaving and pottery, and even of sedentary lifestyles, metallurgy and agriculture. As one Bavove initiate from Koulamoutou put it, "the Pygmies invented everything". And so Blacks credit Pygmies with creating even those things they do not possess and which serve precisely to distinguish the former from the latter (sedentarity, metallurgy and agriculture). This is the mythical context in which we have to place local claims that Bwiti originates with Pygmies: the Pygmies' neighbours credit them with inventing their own rites. This image of the civilizing Pygmy is widespread in Central Africa (Bahuchet \& Guillaume 1979, Klieman 2003) and rests on an inversion of people's lived reality. Another myth helps us to measure the true distance between the original Pygmy and the contemporary Babongo. It tells of the separation of the three "races" that make up 
humanity: Pygmies, Blacks and Whites (Gollnhofer \& Sillans 1997: 145-147) ${ }^{18}$. Their father presents them with three chests and says that each of them must choose one. The Black man chooses the largest chest, full of axes and machetes - he is condemned to manual labour. The White man chooses the smallest chest, containing paper and pencils - he will master writing and so is destined to take command. The Pygmy meanwhile ignores the chest and heads back into the forest to look for honey. The Pygmy here is no longer presented as a heroic civilizing figure, but via his traditional, civilization-renouncing lifestyle: from the point of view of their neighbours, who consider themselves to be more "evolved", the Pygmies have chosen to remain "savages". This myth explains how Pygmies can be considered the Blacks' original ancestors, whilst simultaneously differing by virtue of their preference for forest life. As one urban Bapunu woman elegantly put it, the Pygmies are "our brothers who remained in the bush". In short, the Pygmies' neighbours represent them in strikingly ambivalent ways: on the one hand, the image of the Pygmy as despicable savage (used to justify his subjection), and on the other, the exaltation of the primordial Pygmy in ritual and in myth. As one Bwiti initiator from Libreville succinctly put it, "the Pygmies are both our Gods and our slaves".

Following Igor Kopytoff (1987), Kairn Klieman (2003) suggests that the relational dynamic between allochthones and autochthones that produces the figure of the primordial Pygmy in Central Africa is to be found throughout the whole Niger-Congo region. The incoming Bantu populations needed the (at least symbolic) support of the Pygmies, whom they considered to be the land's autochthonous inhabitants, in order to establish their domination. And so they incorporated representations of them into their rites so as to arrogate

\footnotetext{
${ }^{18}$ This is a ternary variant of an origin myth of differences between Blacks and Whites that is widespread throughout Africa (Görög 1968) and which draws on Biblical narratives such as the curse of Canaan, and the rivalry between Isaac's children.
} 
their power to themselves. This perhaps explains why Pygmies today occupy eminent roles in the Mitsogo's Bwiti. This ritual incorporation is based on a relational logic that does not apply only to Pygmies. Indeed, their place in their neighbours' initiation rites is equivalent to that of women vis-à-vis male initiates. Outside the ritual context, both women and the Babongo are placed in a subordinate position within a relationship of complementary hierarchy (sexual hierarchy for women and economic hierarchy for Pygmies). The relationship is inverted in initiation rites' origin myths, with initiates attributing the origins of their rituals to Pygmies and women (Bonhomme 2006: 177-190). Mwiri was supposedly discovered by women during a fishing party, before being expropriated by men (a similar narrative schema also appears in Bwiti). This act of expropriation enacts men's appropriation of female fertility: through the ritual, initiates claim to re-engender novices and make men of them without the need for women. In the same way, the myth of Bwiti's Pygmy origins can be seen as a ritual appropriation of powers associated with the forest world ${ }^{19}$. Male initiation rites enact the capturing of women's and Pygmies' powers following the same logic of relationality ${ }^{20}$.

This ritual appropriation operates via a process of identification with the primordial Pygmy. In the words of one Eshira initiate from Libreville, "During Bwiti, we become like our parents were, when they were like Pygmies in the forest". Initiates sometimes claim imaginary Pygmy ancestors, especially in urban contexts (the further away the Pygmies are, the easier it is to identify with them). This identification is enacted during ceremonies and

${ }^{19}$ The Babongo's reluctance to initiate their neighbours into Mudimu is nonetheless seen by the latter as evidence of their failure to entirely appropriate the Pygmies' power.

${ }^{20}$ Bwiti also performs the capturing of the White man's power, although outside the ritual context White men occupy the opposite end of the social spectrum to women and Pygmies (Bonhomme 2010). 
signals both a return to one's origins and an appropriation of the savage world of the forest. Initiates dress in leaves and animal hides and transform into forest spirits, which correspond to their fantasised version of Pygmies. One ritual sequence evokes this primordial Pygmy figure. Two initiates grasp each other by the waist and begin to spin frenetically. This is followed by a strange song limited to glottal grunts. Initiates claim that these represent the Bwiti's "original" songs and dances, when the ancestral Pygmies had not yet mastered singing and rhythmic dance.

The Pygmy figure occupies a central place in Bwiti epistemology. The transmission of initiatory knowledge is surrounded by secrecy. Initiates gain access to different information according to their status and their Bwiti "age". A junior member will have access to a secret, but there will always be a further level of explanation available only to his elders. Initiatory knowledge has a layered structure organised around a pair of genealogical and spatial metaphors - deepening one's initiation knowledge is a matter of simultaneously reaching back towards the ancestors and heading further into the forest. The mythical Pygmy figure exists where these two metaphors meet and is therefore associated with the most secret level of knowledge. Initiation teaching takes place in the forest, in a set-aside place called nzimbe or bwenze. When they speak of the "deepest" secrets, initiates do not hesitate to remove their clothing, thus enacting the return to their savage origins. The Pygmy figure is also present in representations of the initiation language. Initiates use a secret language "to speak Bwiti", transforming ordinary language by dint of metaphorical transpositions and loan-words from neighbouring languages ${ }^{21}$. Among the Bavove (also known as Puvi), this secret language is known as mitimbo and is symbolically associated with Pygmies.

${ }^{21}$ Because of the importance of lexical loan-words, the initiation language is often thought of a pidgin, which mixes up elements from the languages of all the different populations that the 
Mitimbo - that's Bwiti language. Puvi mitimbo. Puvi, you'll get to see him. But you can't see mitimbo. The old Puvi man, the one who knows, the doyen, you can't see him. He's a Pygmy. If he wants to explain real Bwiti to you, he will. If he doesn't, he'll explain you lies. Each race has its Pygmies. The true Puvi are the ones in the forest, the Pygmies. The Puvi, that's us villagers. But you cannot understand Bwiti until you go to the Pygmies. The true ones are hidden.

For this Bavove initiator, the figure of the Pygmy hidden in the forest evokes the dissimulation that is at the root of the transmission of initiatory knowledge. Initiates, just like Pygmies, like to cover their tracks: they lie, twist and stall so as to keep some secrets back from their juniors, in order to maintain their authority over them. Bwiti's final secret is as ungraspable as the Pygmies themselves.

\section{THE MYTH MADE REALITY: BABONGO PARTICIPATION IN THEIR NEIGHBOURS' RITES}

Mythical representations of Pygmies play an essential role in Bwiti, but the Babongo also often participate in the ceremonies. In villages where Babongo live nearby, Bwiti organisers requisition "their" Pygmies to take part in the all-night-long ceremonies. The presence of Pygmies is not strictly necessary, but it is highly welcome, as it provides a ritual instantiation of the mythical Pygmy. As one Masango from Ogooué-Lolo put it, "When a Pygmy takes part in Bwiti, his role is like a White man. He's the boss, because he's got all the power that we took. He can be really useful. Bwiti isn't for Pygmies, but they are present”. Thus for one night, real and mythical Pygmies coincide. In a similar way, in one Bwiti

Bwiti ritual has passed through. This recalls that other linguistic admixture - Ebongwe, the Babongo's language. 
sequence, two women known as yombo are called to embody a mythical maternal figure, called Disumba, by grating red padouk wood (which is a fertility symbol). However, the Babongo remain subordinate ritual auxiliaries and their neighbours keep control of the initiation society (just as the yombo remain subordinate). They are not treated with any particular reverence and are sent home once the ceremony is complete, sometimes without having been offered either food or lodging. One Babongo informant from Makoko complained that "When there is a Bwiti, they always say "Come along!", but it's not so easy to find somebody who'll offer you a place to sleep, or even food and wine".

The Babongo are also in charge of the entertainment at their neighbours' ceremonies. Pygmies are renowned for their skill as dancers, singers and musicians and are highly regarded as masters of ceremonies throughout Central Africa. The Babongo live up to this reputation. Thus, the musical bow player is normally a Babongo - which situation recalls the instrument's origin myth (Sallée 1985: 267). There was even a branch of Bwiti based on their role as masters of ceremonies. This branch, called Bwiti Akoa (literally "Pygmy Bwiti"), was popular until the mid-twentieth century on the Gabonese coast. It was a dance of rejoicing during which dancers competed in performing acrobatic tumbles (Mboumba 1988). Bwiti Akoa was a profane version of Bwiti Disumba, which retained the ritual's spectacular elements whilst losing its initiatory role. No use was made of eboga and there were no religious visions or transmission of initiatory knowledge. The only initiatory aspect of the ritual was the administration of a "vaccine" that helped participants acquire their acrobatic prowess. Most dancers were Akoa Pygmies who performed the ritual for the entertainment of their Myene neighbours: "Alongside the Mitsogo and Apindji, Pygmy slaves were also renowned Bwiti dancers. One of them, a man called Kouba from the Pointe Denis, was famous for a long time throughout the Estuary region for his pirouettes, somersaults, flips, 
sleight of hand $[\ldots]$ and for his chaotic movements when the excitement reached a pitch. He died around the time of the First World War" (Raponda-Walker \& Sillans 1962: 210).

Though they are normally confined to a subordinate position, the Babongo play a key role in regional dynamics of ritual circulation and innovation. Famed for their song-writing skill, they also help spread these songs and do not hesitate to adapt musical pieces from one ritual to another. Their geographic situation also helps them in their role as transmitters of ritual. The Chaillu mountains form a vast ensemble of dense, hilly and quite isolated forest, with few inhabitants. There are, for instance, no direct roads between the small towns of Ikobey, Eteke and Iboundji. This triangle of forest, known as Diboa, constitutes the historical heartland of Bwiti, as well as the Babongo's principal zone of settlement. These latter serve as linchpins connecting the different local populations, who all practise Bwiti. The Pygmies' role as ritual innovators can also be attributed to their lifestyle and social organisation, which are respectively more mobile and more fluid than those of their neighbours (Tsuru 2001). They are less dependent on cult leaders, who ensure a certain ritual orthodoxy in neighbouring populations. The Babongo, in contrast, are characterised by a creative indiscipline that their neighbours condemn as disorderly.

The Babongo play an especially important role in Bwiti Misoko. If local metaphor describes Disumba as the trunk of Bwiti, then Misoko is a side-branch (Bonhomme 2006). In Gabon, the sphere of initiation is traditionally structured by an opposition between male religious visions and female therapeutic possession (Mary 1983). In the southern half of the country, Bwiti Disumba marks a contrast with the different local variants of female possession cults (Ombudi, Mabanzi, Elombo, etc.). Bwiti Misoko, on the other hand, is a hybrid ritual as, though it remains centred around visions, these are less religious than divinatory. It is a rite of affliction: it is misfortune that leads people to join the cult and their initiatory visions are principally concerned with identifying the witch at the root of the problem. Initiators called 
nganga-a-Misoko also act as healers and diviners. Misoko can be further broken up into subbranches. The earliest of these comes from the Mitsogo and is called Myobe. Ngonde is a more recent and more spectacular branch, which specialises in divination and comes from the Bavove. Bwiti Misoko Ngonde probably emerged in the first half of the $20^{\text {th }}$ century and has, since the 1980s, spread throughout the country, displacing Myobe and Disumba ceremonies. It is firmly established in the southern half of the country as well as in most urban centres. Its success is down to a few great initiates, who have undertaken full-scale initiation tours of the country, proselytising as they go and creating new "temples" (mbandja), which they then entrust to their "Bwiti children". In the Chaillu mountains, the rise of Misoko has shifted the centre of initiatory activity eastwards. The range's western reaches are populated by the Mitsogo and Apindji, who specialise in Disumba, whereas Misoko is associated with the Masango, Bavove and Simba further to the east. The Babongo, who live on the border between these two zones, play a key role in the ritual dynamics that have led to Misoko's emergence out of Disumba.

Indeed, Bwiti Misoko is the product of a process of regional ritual synthesis that incorporates Pygmy elements. For instance, Buluma is a propitiatory invocation employed by the Babongo for hunting and is doubtless linked to Mudimu, though it has now fallen into disuse. This invocation has been transplanted into the Misoko ritual. Thus, a Pygmy rite has been embedded in one of their neighbours' rituals as a subsidiary sequence. This link between Mudimu, Buluma and Misoko was confirmed by a Babongo nganga from Mimongo: "Old man Dumu and old man Manumba [famed Misoko initiators] went to the Babongo to be initiated into Buluma. Afterwards, when they invoked their Bwiti, people were shaken by spirits. You can't be a real nganga until you're initiated into Mudimu". The idea that Buluma has been transposed into Bwiti is further confirmed by the presence of two separate invocations (Mwago and Buluma) in Misoko, whereas originally Disumba only had Mwago (a 
long prayer addressed to the ancestors). Buluma, in contrast, is much briefer and is linked to hunting and divination. It speaks of spear-hunting, hounds, tracking and game. According to initiates' interpretations, it is a "consultation done before the hunt so that the Bwiti will indicate the path leading to good bush". There is a strong symbolic association between hunting and divination. Diviners are compared to a hunter and his dog: they sniff out witchcraft like a hunting dog sniffs out game (one of their techniques consists of smelling the patient's hand). On its way from the Babongo to their neighbours, Buluma went from being an act of cynegetic propitiation to one of therapeutic divination, with its hunting symbolism being adapted to the new register. This kind of transposition is common in Central Africa: rituals used by Pygmies for hunting are used by their neighbours for healing (Andersson 1983: 107). Pygmies, unlike their neighbours, are more interested in hunting than in witchcraft.

Bwiti Misoko Ngonde incorporates Babongo elements, but does this mean that it originates with the Pygmies? The Masango and Babongo who cohabit in villages between Mimongo and Koulamoutou both often say that, though Disumba went from the Mitsogo to the Masango and from there to the Babongo, Misoko went from the Babongo to the Bavove and thence to the Masango. This, however, is contradicted by individual initiatory genealogies. Most Babongo Misoko practitioners were initiated by their neighbours, rather than by other Babongo. In the eastern part of the Chaillu mountains, the Babongo were often initiated by Bavove and Simba. To the west, the chains of initiation are yet more convoluted. Babongo from villages around Ikobey were not initiated by their immediate neighbours (the Mitsogo, who generally practise Disumba), but by a Bapunu man called Desayo, renowned throughout the country. This latter, one of the ritual entrepreneurs who helped popularise Misoko, has initiated hundreds of people since the 1970s. Though the mythical Pygmy is held 
to be the first Bwiti initiate, the Babongo are in fact quite often the very last links in the chain of transmission.

Nowadays, however, there are many Babongo Bwiti Misoko initiators. The Babongo mainly specialise in Misoko rather than Disumba, into which they may be initiated but are rarely initiators. It is notable that in a mixed village like Mukandi, the Disumba mbandja (temple or men's house) is Masango, whilst the Misoko temple is Babongo. For everyone except the Babongo, the Bwiti Disumba is one of the cornerstones of ethnic identity in the Chaillu mountains. Being a "real" Mitsogo or Apindji means being an initiate. An unitiated man cannot enter the men's house and take part in collective decision-making. The institution of initiation plays an essential role in the reproduction of local social organisation. Propped up by the local ancestor cult, Disumba serves to reinforce and legitimise male elders's domination of women, juniors and dependents. It is, in Ioan Lewis's (1971) terms, a central cult, whose religious and political functions are intrinsically intertwined. As they are dominated by their neighbours, the Babongo are confined to a subordinate role in Bwiti Disumba. Bwiti Misoko, on the other hand, isn't associated with any particular ethnic identity and has a more individual dimension. This branch of the cult is engaged in a process of peripheralisation, whereby Bwiti becomes detached from the traditional ancestor cult, loses its political centrality and takes on a therapeutic and divinatory role ${ }^{22}$. The assertion and legitimation of male elders' authority is no longer really central to the cult. Bwiti Misoko is more detached from local social organisation and therefore presents the Babongo with an opportunity to emancipate themselves from their neighbours' ritual supervision - it is easier

\footnotetext{
${ }^{22}$ For a discussion of processes of centralisation and peripheralisation of cults, see also Berger 2010.
} 
for them to hold important positions ${ }^{23}$. Misoko, then, started to appeal to the Babongo just as it was coming to wider national attention. It is no coincidence that around this time some Misoko communities began to admit female initiates, known as mabundi. Bwiti Misoko allowed for the simultaneous emancipation of the Babongo and of women, both of whom had up until then been caught up in a relationship of initiatory domination.

The Pygmies are famed throughout Central Africa for their knowledge of the healing properties of plants and often specialise in nganga healer-diviner activities. The Baka, for instance, treat their neighbours - the same neighbours from whom they learnt all their nganga rituals (Tsuru 1998). In Gabon, where initiation rites are still very common, a nganga career is doubly attractive because it connotes membership of a prestigious and widely implanted ritual corporation. Nowadays, the Babongo are famous in the whole of Gabon as excellent nganga-a-Misoko and people come from afar to be treated or initiated by them (Matsuura 2010). Some Babongo villages have even developed a proper trade in religious healing. Urban initiates perform pilgrimages to Pygmy villages to acquire ritual prestige. Babongo nganga are in demand as far afield as Libreville. The Babongo who live near Butumbi even benefit from a brand new mobile phone tower in the surrounding area that enables them to directly get in touch with potential clients in town, hence bypassing their Masango neighbours (Matsuura, personal communication). It is not unknown for political elites to ask Pygmies to "bulletproof" them against their rivals. Thanks to the Misoko, Bwiti may have lost its local political centrality, but it has become a ritual resource that can be deployed in political

${ }^{23}$ S. Fürniss (2008) describes a similar situation among the Baka Pygmies of Cameroon. Whereas Eastern Baka remain subordinate actors in the circumcision ritual of their Kwele and Bangando neighbours, Western Baka have borrowed this ritual from the Bangando and have now become specialists in charge of their own neighbours' circumcision. 
competition at the national level. Specialised as it is in the management of fortune and misfortune, Misoko is well adapted to political modernity, to its risks and to its unpredictability.

Pygmies' new ritual prestige even extends to "White men". The last ten years have seen the emergence of initiation tourism in Gabon (Chabloz 2009). Most tourists go no further than Libreville, but some brave souls visit the Babongo to be initiated. These Westerners often share a primitivist conception of Pygmies which partially overlaps with local representations of them. Considered to be "first people", they are thought to practise a more authentic form of Bwiti than their neighbours. This trade in religious healing generates more revenue than the sale of forest produce. Bwiti Misoko, then, allows Pygmies to attain desirable social status and sometimes even to take a wife from among their neighbours' women. For the neighbours, and especially for the Mitsogo, this is highly unwelcome. They have trouble coming to terms with "their" Pygmies being emancipated and are unhappy about the foreigners who come to be initiated by the Babongo rather than by themselves, whom they consider the original practitioners of Bwiti. In short, Bwiti Misoko is the Pygmies' revenge on their neighbours. By becoming specialists in their neighbours' rites, they have ironically transformed the Bwiti myth of the primordial Pygmy into reality (just as mabundi can be seen as somehow enacting the myth of the ritual's female origin). Thus the Babongo have finally assimilated the figure of "the Pygmy" created for them by their neighbours, and in so doing they have further blurred the lines between myth and reality. 
In this article we have focussed on the ritual performance of relations between Babongo Pygmies and their neighbours, looking at the ways in which initiation rites allow for the renegotiation of social ties contracted outside the ritual context. To this end, we have endeavoured not to constrict the case study with restrictive ethnography, trying instead to situate it within wider patterns of ritual logic and dynamics of ritual change within the region. The Babongo are to their neighbours as women are to men. Outside the context of initiation, both women and the Babongo occupy subordinate positions in the relationships of complementary hierarchy that respectively link them to men and to neighbouring populations. Bwiti inverses this relational form by placing women and Pygmies at the origin-point of the ritual and of its power. This dual mythical origin is enacted via their actual participation in ceremonies, however their presence remains subordinate to the mythical representations controlled by cult leaders. The Babongo who perform at Bwiti Disumba ceremonies are supposed to embody the "Pygmy" as he is construed by their neighbours. In similar fashion, the two women who grate padouk during one ritual sequence are supposed to embody "woman" as she is construed by men (indeed, they can also be replaced by initiates dressed as women). Both the Babongo and women are present not because of what they are, but because of what they represent in a ritual organised entirely from the perspective of male elders. The relationship between myth and ritual or, more precisely, between representations and action in the ritual context, remains strictly controlled by cult leaders. Confined to subaltern roles, neither women nor the Babongo have any scope for innovation. Bwiti Disumba plays a central role in the reproduction of male elders' domination of their juniors, women and dependents in the village community.

The Babongo's status has also been affected by the profound changes undergone by Bwiti over the course of the $20^{\text {th }}$ century and the national expansion of Bwiti Misoko since the 1980s constitutes a significant turning point. The shift from Disumba to Misoko has seen the 
cult take a therapeutic turn and become increasingly peripheralised: as the links to the ancestor cult and the dominance of elder men have been gradually weakened, Bwiti has lost its political centrality. This decoupling of ritual from local social organisation has allowed for the emancipation of subordinate social actors. Junior men flood the initiatory sphere (particularly in urban areas), by-passing their elders and forging a career as "father-initiator". Women too are more and more present and no longer hesitate to challenge men's initiatory authority, asserting the independence of Mabundi, their own branch of Bwiti. As for Babongo Pygmies, they are no longer mere ritual entertainers serving their neighbours and have become renowned nganga in competition with their former initiators. This initiatory emancipation renegotiates the relationship between ritual and myth, which had until recently been controlled by the cult leaders. In becoming full-blown ritual actors, both the Babongo and women enact the Bwiti's origin myth on their own account. The shift in Pygmies' initiatory status is part of a wider process of recomposition of the field of religious healing which has seen subaltern actors emerge as central participants on the ritual scene. 


\section{REFERENCES}

\section{Althabe, Gérard}

1965 Changements sociaux chez les Pygmées Baka de l'Est-Cameroun. Cahiers d'études africaines 20: 561-592.

\section{Andersson, Efraim}

1983 Les Bongo-Rimba. Uppsala: Almqvist \& Wiksell.

\section{Arom, Simha, and Jacqueline M.C.Thomas}

1974 Les Mimbo, génies du piégeage, et le monde surnaturel des Ngbaka-mábo. Paris: SELAF.

\section{Bahuchet, Serge}

1991 Les Pygmées d'aujourd'hui en Afrique centrale. Journal des Africanistes 61/1: 5-35.

1992 Dans la forêt d'Afrique Centrale: les Pygmées Aka et Baka. Paris: Peeters-SELAF.

1993a La rencontre des agriculteurs: les Pygmées parmi les peuples d'Afrique centrale. Paris: Peeters-SELAF.

1993b L’invention des Pygmées. Cahiers d'études africaines 129: 153-181.

2007 Les Pygmées du Gabon. In: J.M. Hombert and L. Perrois (eds), Cœur d'Afrique: gorilles, cannibales et Pygmées dans le Gabon de Paul Du Chaillu; pp. 140-145. Paris: CNRS.

\section{Bahuchet, Serge, Guillaume, Henri}

1979 Relations entre chasseurs-cueilleurs pygmées et agriculteurs de la forêt du nord-ouest du bassin congolais. In: S. Bahuchet (ed.), Pygmées de Centrafrique; pp. 109-139. Paris: SELAF.

\section{Barth, Fredrik}


1969 Ethnic groups and boundaries: the social organization of culture difference. Boston: Little, Brown \& co.

\section{Bazin, Jean}

1985 A chacun son Bambara. In: J.L. Amselle and E. M'Bokolo (dir.), Au cœur de l'ethnie. Ethnies, tribalisme et État en Afrique; pp. 87-127. Paris: La Découverte.

\section{Berger, Laurent}

2010 La centralisation d'un culte périphérique. Islam, possession et sociétés d'initiation au Bèlèdugu (Mali). Politique africaine 118: 143-164.

\section{Blench, Roger}

1999 Are the African Pygmies an Ethnographic Fiction? In: K. Biesbrouck, S. Elders, and G. Rossel (eds), Central African Hunter-Gatherers in a Multidisciplinary Perspective: Challenging Elusiveness; pp. 41-60. Leiden: Research School for Asian, African and Amerindian Studies (CNWS), Universiteit Leiden.

\section{Bonhomme, Julien}

2006 Le Miroir et le crâne. Parcours initiatique du Bwete Misoko. Paris: CNRS-MSH.

2007 Transmission et tradition initiatiques en Afrique centrale. Annales Fyssen 21: 48-60.

2010 Masque Chirac et danse de Gaulle. Images rituelles du Blanc au Gabon. Gradhiva N.S. 11: 80-98.

\section{Boyer, Pascal}

1989 Pourquoi les Pygmées n’ont pas de culture ? Gradhiva 7: 3-17.

\section{Chabloz, Nadège}

2009 Tourisme et primitivisme. Initiations au bwiti et à l'iboga (Gabon). Cahiers d'études africaines 193-194: 391-428.

\section{Cheyssial, Jean-Claude}

2000 Le peuple de la forêt. DVD movie (48 min.). La Luna Production - RFO 


\section{Dapper, Olfert}

1686 Description de l'Afrique. Amsterdam: Wolfgang, Waesberge, Boom \& Van Someren.

\section{Delobeau, Jean-Michel}

1989 Yamonzombo et Yandenga: les relations entre les villages monzombo et les campements pygmées aka dans la sous-préfecture de Mongoumba, Centrafrique. Paris: Peeters-SELAF.

\section{De Ruyter, Magali}

2003 La musique des Bongo du Gabon. Nanterre (M.A. thesis in ethnomusicology, Université Paris-X).

\section{Deschamps, Hubert}

1962 Traditions Orales et Archives au Gabon. Contribution à l'ethnohistoire. Paris: Berger Levrault.

\section{Du Chaillu, Paul Belloni}

1867 A Journey to Ashango-Land and Further Penetration into Equatorial Africa. New York: D. Appleton \& Co.

1872 The Country of the Dwarfs. New York: Harper \& Brothers.

\section{Fernandez, James W.}

1982 Bwiti. Ethnography of religious imagination in Africa. Princeton: Princeton University Press.

\section{Frankland, Stanley}

1999 Turnbull's syndrome. Romantic fascination in the rain forest. In: K. Biesbrouck, S. Elders, and G. Rossel (eds), Central African hunter-gatherers in a multidisciplinary perspective: Challenging elusiveness; pp. 61-73. Leiden: Research School for Asian, African and Amerindian Studies (CNWS), Universiteit Leiden.

\section{Fürniss, Susanne}


2008 The adoption of the circumcision ritual bèkà by the Baka-Pygmies in Southeast Cameroon. African Music 8/2: 94-113.

Gambeg, Yvon-Norbert, Nobert Gami, and Patrice Bigombe Logo

2006 L'insertion des pygmées du Congo dans l'économie moderne. In: S. C. Abega, and P. Bigombe Logo (dir.), La marginalisation des pygmées d'Afrique centrale; pp. 125139. Paris: Maisonneuve \& Larose - Afrédit.

\section{Gell, Alfred}

1998 Art and agency: an anthropological theory. Oxford: Clarendon Press.

\section{Gollnhofer, Otto, and Roger Sillans}

1997 La mémoire d'un peuple. Ethno-histoire des Mitsogho, ethnie du Gabon central. Paris: Présence Africaine.

\section{Görög, Veronika}

1968 L'origine de l'inégalité des races. Études de 37 contes africains. Cahiers d'études africaines 30: 290-309.

\section{Grinker, Roy Richard}

1990 Images of denigration: structuring inequality between foragers and farmers in the Ituri forest, Zaire. American Ethnologist 17/1: 111-130.

\section{Guille-Escuret, Georges}

1998 La révolution agricole des Pygmées aka. De la structure dans l'événement et réciproquement. L'Homme 147: 105-126.

\section{Handelman, Don}

1990 Models and mirrors: Towards an anthropology of public events. Cambridge: Cambridge University Press.

Headland, Thomas N., and Lawrence A. Reid 
1989 Hunter-Gatherers and Their Neighbors from Prehistory to the Present. Current Anthropology 30/1: 43-66.

\section{Houseman, Michael}

2006 Relationality. In: J. Kreinath, J. Snoek, and M. Stausberg (eds), Theorizing Rituals. Issues, Topics, Approaches, Concepts; pp. 413-428. Leiden: Brill.

\section{Houseman, Michael, and Carlo Severi}

1998 Naven or the other self: a relational approach to ritual action. Leiden: Brill.

\section{Joiris, Daou V.}

1993 Baka Pygmy hunting rituals in Southern Cameroon: How to walk side by side with the elephant. Civilisations 41/2: 51-89.

1997 Les Pygmées du Gabon. In L. Perrois (ed.), L’esprit de la forêt. Terres du Gabon; pp. 53-61. Paris-Bordeaux: Somogy-Musée d'Aquitaine.

2003 The framework of central African hunter-gatherers and neighbouring societies. African Study Monographs suppl. 28: 57-79.

\section{Kapferer, Bruce}

1979 Ritual Process and the Transformation of Context. Social Analysis 1: 3-19.

\section{Kazadi, Ntole}

1981 Méprisés et admirés: l'ambivalence des relations entre les Bacwa (Pygmées) et les Bahemba (Bantu). Africa 51/4: 836-847.

\section{Klieman, Kairn A.}

2003 "The Pygmies Were Our Compass": Bantu and Batwa in the history of west central Africa, early times to c. 1900 C.E. Portsmouth: Heinemann.

\section{Knight, Judy}

2003 Relocated to the Roadside: Preliminary Observations on the Forest Peoples of Gabon. African Study Monographs suppl. 28: 81-121. 


\section{Kopytoff, Igor}

1987 The African Frontier: The Reproduction of Traditional African Societies. Bloomington: Indiana University Press.

\section{Le Roy, Alexandre}

1928 Les Pygmées: négrilles d'Afrique et négritos d'Asie. Paris: Beauchesne. [1905]

\section{Lewis, I.M.}

1971 Ecstatic religion. An anthropological study of spirit possession and shamanism. Harmondsworth: Penguin Books.

\section{Mary, André}

1983 L'alternative de la vision et de la possession dans les sociétés religieuses et thérapeutiques du Gabon. Cahiers d'études africaines 91: 281-310.

2010 La preuve de Dieu par les Pygmées. Le laboratoire équatorial d'une ethnologie catholique. Cahiers d'études africaines 198-199: 881-905.

\section{Matsuura, Naoki}

2006 Sedentary Lifestyle and social relationship among Babongo in Southern Gabon. African Study Monographs suppl. 33: 71-93.

2007 Shared Rituals and Interethnic Relationships Between the Babongo and Massango of Southern Gabon (in Japanese). Journal of African Studies 70: 1-14.

2009 Visiting patterns of two sedentarized central African hunter-gatherers: comparison of the Babongo in Gabon and the Baka in Cameroon. African Study Monographs 30/3: 137-159.

2010 Relations with Outside World through Traditional Rituals of the Babongo Pygmies in Southern Gabon (in Japanese). Journal of African Studies 77: 19-30.

\section{Mayer, Raymond}

1987 Langues des groupes Pygmées au Gabon: un état des lieux. Pholia 2: 111-124. 


\section{Mboumba, Séraphin}

1988 Observation systématique d'une technique du corps : cas du Bwiti y'Akowa chez les Orungu. Libreville. (B.A. thesis in psychology, Université Omar-Bongo).

\section{Museur, Michel}

1969 Récentes perspectives sur la culture des Mbuti. Cahiers d'études africaines 33: 150159.

Patin, Etienne, et al.

2009 Inferring the Demographic History of African Farmers and Pygmy Hunter-Gatherers Using a Multilocus Resequencing Data Set. PLoS Genetics 5/4.

\section{Quintana-Murci, Lluis, et al.}

2008 Maternal traces of deep common ancestry and asymmetric gene flow between Pygmy hunter-gatherers and Bantu-speaking farmers. Proceedings of the National Academy of Sciences 105/5: 1596-1601.

\section{Raponda-Walker, André}

1996 Éléments de grammaire ébongwé (Langue des Pygmées) Libreville: Raponda-Walker ed. [1937].

1998 Au pays des tsogo. Libreville: Raponda-Walker ed. [1910].

2002 Notes d'histoire du Gabon. Libreville: Raponda-Walker ed. [1960].

Raponda-Walker, André, and Roger Sillans

1962 Rites et croyances des peuples du Gabon. Paris: Présence Africaine.

\section{Rey, Pierre-Philippe}

1971 Colonialisme, néo-colonialisme et transition au capitalisme: exemple de la Comilog au Congo-Brazzaville. Paris: Maspero.

\section{Rupp, Stephanie}


2003 Interethnic relations in Southeastern Cameroon: challenging the "hunter-gatherer" “farmer” dichotomy. African Study Monographs suppl. 28: 37-56.

\section{Sallée, Pierre}

1985 L'arc et la harpe. Contribution à l'histoire de la musique du Gabon. Nanterre . (Ph.D. thesis in ethnomusicology, Université Paris-X).

\section{Schebesta, Paul}

1940 Les Pygmées. Paris: Gallimard.

\section{Soengas, Beatriz}

2009 Preliminary ethnographic research on the Bakoya in Gabon. African Study Monographs 30/4: 187-208.

\section{Swiderski, Stanislaw}

1979 Les récits bibliques dans l'adaptation africaine. Journal of Religion in Africa 10/3: 174-233.

\section{Terashima, Hideaki}

1998 Honey and holidays: the interactions mediated by honey between Efe hunter-gatherers and Lese farmers in the Ituri forest. African Study Monographs suppl. 25: 123-134.

\section{Trilles, Henri}

1932 Les Pygmées de la forêt équatoriale. Paris: Bloud \& Gay.

\section{Tsuru, Daisaku}

1998 Diversity of Ritual Spirit Performances Among the Baka Pygmies in Southeastern Cameroon. African Study Monographs suppl. 25: 47-84.

2001 Generation and transaction processes in the spirit ritual of the Baka Pygmies in Southeast Cameroon. African Study Monographs suppl. 27: 103-123.

\section{Turnbull, Colin M.}


1957 Initiation Among the BaMbuti Pygmies of the Central Ituri. Journal of the Royal Anthropological Institute of Great Britain and Ireland 87/2: 191-216.

1960 Field Work Among the Bambuti Pygmies, Belgian Congo: A Preliminary Report. Man 60: $36-40$.

1965 Wayward servants: the two worlds of the African pygmies. Garden City [NY]: American Museum of Natural History - Natural History Press.

\section{Vansina, Jan}

1990 Paths in the rainforests: toward a history of political tradition in equatorial Africa. Madison: University of Wisconsin Press.

\section{Verdu, Paul et al.}

2009 Origins and Genetic Diversity of Pygmy Hunter-Gatherers from Western Central Africa. Current Biology 19/4: 312-318. 